\title{
MEMPELAJARI VIABILITAS ENKAPSULASI SEL PROBIOTIK (LACTOBACILLUS PLANTARUM DAN STREPTOCOCCUS THERMOPHILUS) PADA ES KRIM
}

\author{
( Study Viability Encapsulation of Probiotic Cells (Lactobacillus plantarum and \\ Streptococcus thermophilus) on Ice Cream)
}

\author{
Maryati Bilang $^{1 *}$, Mulyati Tahir ${ }^{1)}$, dan Darmayanti Haedar ${ }^{1)}$ \\ ${ }^{1 *)}$ Program Studi Ilmu dan Teknologi Pangan Departemen Teknologi Pertanian Universitas Hasanuddin \\ Makassar, Indonesia \\ *)email Penulis Korespondensi: mariyati_tekpert@yahoo.com
}

\begin{abstract}
ABSTRAK
Enkapsulasi adalah salah satu metode untuk melindungi bakteri dalam kondisi lingkungan yang tidak menguntungkan seperti pengolahan, penyimpanan dan pencernaan. Tujuan dari penelitian ini adalah untuk menyelidiki efek enkapsulasi Lactobacillus plantarum dan Streptococcus thermopillus pada es krim selama penyimpanan beku (-28oC). Penelitian ini juga untuk menyelidiki ketahanannya terhadap kondisi asam lambung $(\mathrm{pH} 2,0)$ dan garam empedu (0,5\%), dan efeknya pada es krim organoleptik dan overrun. Enkapsulasi dilakukan menggunakan teknik emulsi dengan natrium alginat sebagai pelapis. Resistensi bakteri dilihat dari jumlah total Bakteri Asam Laktat selama penyimpanan. Hasil penelitian menunjukkan bahwa tidak ada perbedaan yang signifikan $(\mathrm{P}>0,05)$ pada organoleptik es krim Lactic Acid Bacterial yang dienkapsulasi dan tidak selama penyimpanan. Nilai overrun es krim asam laktat bebas lebih besar daripada es krim dalam bakteri asam laktat yang dienkapsulasi. Hasil penelitian menunjukkan bahwa ada perbedaan yang signifikan $(\mathrm{P}<0,05)$ pada viabilitas Bakteri Asam Laktat yang dikemas dan tidak selama penyimpanan. Lactobacillus plantarum dan Streptococcus thermopillus tanpa enkapsulasi telah berkurang sebanyak 1,25CFU Log g1 (12\%) dan 2,56 CFU Log g-1 (25\%). Sedangkan Lactobacillus plantarum dan Streptococcus thermopillus dengan encapsulated orespectively menurun menjadi 0,20 log CFU g-1 (2\%) dan 1.45CFU Log g-1 (14\%) setelah penyimpanan delapan minggu. Demikian pula, dalam kondisi asam lambung pH 2 dan garam empedu 0,5\%, Bakteri Asam Laktat yang dienkapsulasi memiliki ketahanan yang lebih baik daripada bakteri asam laktat yang tidak dienkapsulasi. Oleh karena itu, bakteri asam laktat yang dienkapsulasi memiliki viabilitas yang lebih baik terhadap suhu beku, asam lambung dan garam empedu selama penyimpanan beku.
\end{abstract}

Kata Kunci : es krim, probiotik, Lactobacillus plantarum, Streptococcus thermopillus, enkapsulasi

\section{ABSTRACT}

Encapsulation is one of the methods of protecting bacteria in unfavorable environmental conditions such as processing, storage and digestion. The aim of this research was to investigate the encapsulation effect of Lactobacillus plantarum and Streptococcus thermopillus on ice cream during frozen storage $(-28 o C)$. The study also was to investigate its resistance to stomach acid condition ( $\mathrm{pH} 2.0)$ and bile salt $(0.5 \%)$, and its effect on organoleptic and overrun ice cream. Encapsulation was performed using an emulsion technique with sodium alginate as a coating. Bacterial resistance was seen from the total amount of Lactic Acid Bacteria during storage. The results showed that there was no significant difference $(P>0.05)$ on the organoleptic ice cream Lactic Acid Bacterial were encapsulated and not during storage. The value of overrun ice cream free lactic acid bacteria 
is greater than the ice cream in encapsulated lactic acid bacteria.The results showed that there was significant difference $(P<0.05)$ on the viability Lactic Acid Bacteria were encapsulated and not during storage. Lactobacillus plantarum and Streptococcus thermopillus without encapsulation has decreased as much 1.25CFU Log g-1(12\%)and 2.56CFU Log g-1 (25\%). While Lactobacillus plantarum and Streptococcus thermopillus with encapsulated orespectively decreased to $0.20 \log C F U$ g-1(2\%) and 1.45CFU Log g-1 (14\%)after eight weeks storage. Similarly, in gastric acid conditions $\mathrm{pH} 2$ and $0.5 \%$ bile salts, encapsulated Lactic Acid Bacteria have better resilience than unencapsulated Lactic Acid Bacteria.Therefore, encapsulated lactic acid bacteria have better viability to freezing temperatures, gastric acid and bile salts during frozen storage.

Keywords : ice cream, probiotic, Lactobacillus plantarum, Streptococcus thermopillus, encapsulation

\section{PENDAHULUAN}

Probiotik merupakan mikroorganisme hidup yang di konsumsi oleh manusia maupun hewan serta bermanfaat bagi kesehatan seperti mencegah diare karena dapat melawan rotavirus, menstimulasi sistem imun, mencegah pembengkakan usus besar (irritable bowel diseases), memberi manfaat bagi penderita intoleran laktosa, mengatasi alergi, menurunkan resiko kanker, mencegah infeksi patogen di saluran pernapasan, mencegah konstipasi, dan menurunkan kolesterol (Schmidt, 2006).

Mikroorganisme probiotik umumnya berasal dari Bakteri Asam Laktat (BAL). Bakteri asam laktat seperti Lactobacillus sp., Streptococcus sp., Leuconostoc sp., dan Pediococcus sp. Lactobacillus plantarum merupakan BAL gram positif homo fermentatif. Bakteri ini dapat tumbuh pada $\mathrm{pH} \quad 3,0-4,6$ memiliki kemampuan menghambat bakteri patogen dan lebih tahan terhadap asam dari pada jenis Streptococcus sp. Streptococcus thermophilus merupakan BAL yang bersifat termodurik, homofermentatif yang memilki $\mathrm{pH}$ optimum 6,5 dan akan terhenti pertumbuhannya pada $\mathrm{pH}$ 4,2-4,4. Selain menghasilkan asam laktat, Streptococcus thermophilusjuga menghasilkan enzim laktase yang berfungsi mencerna laktosa dalam susu (Gilliland, Staley, \& Bush, 1984).

Es krim merupakan hidangan beku yang memiliki kandungan gizi tinggi dan banyak digemari masyarakat. Penggunaan probiotik pada es krim dapat berperan penting dalam mencegah berbagai permasalahan saluran pencernaan. Namun, Selama proses pembekuan es krim kemungkinan dapat terjadi kerusakan sel BAL karena perbedaan sensitivitas untuk setiap jenis mikroba terhadap pembekuan. Kerusakan akibat proses pembekuan ini mengakibatkan perubahan morfologi sel, struktur sel, perubahan fungsi sel BAL dan perubahan stabilitas genetik BAL atau daya tumbuh kembali, sehingga saat dikonsumsi dan di dalam sistem saluran pencernaan jumlah BAL menurun dan tidak mencukupi ketika sampai di kolon.

Menurut (Krasaekoopt, Bhandari, \& Deeth, 2003) dosis yang dibutuhkan untuk mendapatkan efek kesehatan setelah mengonsumsi probiotik tergantung dari strain probiotik yang digunakan. Secara umum efek kesehatan tersebut akan diperoleh bila mengonsumsi probiotik sekitar $10^{6}-10^{7} \mathrm{cfug}^{-1}$ per hari. Jumlah yang cukup menurut (FAO/WHO, 2002) adalah $10^{6} \quad-10^{8} \mathrm{cfu} / \mathrm{g}$ dan diharapkan dapat berkembang menjadi $10^{12} \mathrm{cfu} / \mathrm{g}$ di dalam kolon. Sedangkan menurut International Dairy Federation (IDF) standar jumlah minimum probiotik hidup sebagai acuan adalah $10^{6} \mathrm{koloni} / \mathrm{ml}$ pada produk akhir. Oleh karena itu viabilitas probiotik dalam produk dan selama penyimpanan perlu diperhatikan.

Enkapsulasi merupakan suatu cara untuk melindungi bakteri dari faktor-faktor 
lingkungan yang berbahaya (ekstrim) seperti pemanasan, pembekuan dan $\mathrm{pH}$ rendah bagi bakteri tersebut melalui proses penyalutan atau melapisi suatu zat inti dalam hal ini BAL dengan suatu lapisan dinding polimer. Keuntungan enkapsulasi adalah memiliki membran semipermeabel, bulat, dan kuat sehingga sel bakteri dapat bertahan pada kondisi ekstrim. Berdasarkan hal tersebut, maka penting untuk mengetahui proses mikroenkapsulasi serta pengaruh enkapsulasi terhadap viabilitas BAL (probiotik) di dalam es krim selama penyimpanan beku dan setelah diuji ketahanannya terhadap simulasi asam lambung dan cairan empedu.

Sehingga perlu dirumuskan bagaimana viabilitas dan daya tumbuh kembali sel probiotik Lactobacillus plantarum dan Streptococcus thermopillus terenkapsulasi pada es krim dan selama penyimpanan beku, pengaruh sel Lactobacillus plantarum dan Streptococcus thermopillus terenkapsulasi terhadap cairan asam lambung dan garam empedu secara imulasi serta pengaruh penambahan enkapsulasi probiotik atau BAL terhadap nilai overrun es krim dan bagaimana pengaruh penambahan enkapsulasi probiotik atau BAL terhadap mutu organoleptik es krim.

Tujuan dari penelitian ini adalah mengkaji viabilitas sel probiotik Lactobacillus plantarum dan Streptococcus thermopillus yang terenkapsulasi di dalam es krim selama penyimpanan beku, mengetahui pengaruh ketahanan enkapsulasi terhadap BAL selama berada di dalam simulasi asam lambung dan garam empedu, serta pengaruh penambahan enkapsulasi terhadapat mutu dan daya terima es krim. Hasil dari penelitian ini diharapkan dapat memberi informasi ilmiah mengenai pengaruh enkapsulasi terhadap viabilitas sel probiotik Lactobacillus plantarum dan Streptococcus thermophillus selama penyimpanan beku, di dalam sistem pencernaan serta terhadap mutu es krim.

\section{METODOLOGI PENELITIAN}

\subsection{Alat}

Peralatan yang digunakan dalam penelitian ini meliputi vortex, timbangan analitik, erlenmeyer, gelas piala, hot plate,magnetick stirrer, laminar air flow, autoklaf, inkubator, $\mathrm{pH}$ meter, pipet volume, cawan petri, tabung reaksi, corong penyaring, bunsen, jarum ose,tabung durham,Sentrifugator, Mikroskop, shaker inkubator

\subsection{Bahan}

Bahan yang digunakan dalam penelitian ini adalah natrium alginat (food grade), kultur murni Lactobacillus plantarum (FMIPA-UH) dan Streptococcus thermopillus (UGM), aquades, $\mathrm{CaCl}_{2} 0.1 \mathrm{M}$, minyak kedelai (Mazola), $\mathrm{NaCl}$ (Merck), gliserol, lesitin nabati, bile salt(Himedia),MRS-Broth (Merck), MRSAgar (Merck), kapas, aluminium foil, tissue, buffer fosfatpH 7, $\mathrm{HCl}$ 0,1 M, Alkohol 70\%, $\mathrm{NaOH}$.

\subsection{Prosedur Penelitian}

Penelitian terdiri atas pembuatan bakeri asam laktat terenkapsulasi dan pembuatan es krim probiotik. Kemudian pengamatan terhadap total BALselama penyimpanan pada es krim, serta pada simulasi asam lambung dan garam empedu yang disertai uji $\mathrm{pH}$ dan total asam. Selain itu dilakukan pengamatan organoleptik dan overrun pada es krim probiotik.

\subsubsection{Proses Mikroenkapsulasi}

Masing-masing biomassa kultur murni Lactobacillus plantarum (10,27 Log CFU/ml) dan Streptococcus thermopillus (10,33 Log CFU/ml)sebanyak $12 \mathrm{~mL}$ dimasukkan ke dalam $60 \mathrm{ml}$ larutan natrium alginat $4 \%$ steril dan di homogenkan. Campuran kultur murni dan natrium alginat ditambahkan ke dalam $100 \mathrm{~mL}$ minyak kedelaiyang mengandung $0.2 \%$ lesitin yang diputar konstan dengan pengaduk magnetik (200 rpm). Setelah 5 menit, $100 \mathrm{~mL}$ larutan $\mathrm{CaCl} 20.1 \mathrm{M}$ ditambahkan untuk memecah 
emulsi selama 30 menit. Kapsul-kapsul yang telah terbentuk kemudian dipisahkan dengan cara disentrifugasi (350 rpm) selama 10 menit pada suhu $4 \mathrm{oC}$ dan dicuci dua kali dengan akuades. Manik-manik dipisahkan dengan kertas saring lalu dicuci kembali dengan $0,85 \% \quad \mathrm{NaCl}$ yang mengandung 5\% gliserol, kemudian dipindahkan ke dalam cawan petri steril dan disimpan dalam refrigerator (7-1oC). Bakteri asam laktat setelah dienkapsulasi dihitung melalui disitegrasi pada buffer fosfat $\mathrm{pH} 7.0$ selama 5 menit menggunakan vortex, lalu dilakukan pengenceran dan diinkubasi pada MRSA ke dalam cawan petri pada suhu $37 \mathrm{oC}$ selama 48 jam.

\subsubsection{Pembuatan Es Krim}

Es krim di buat dengan komposisi ekstrak terung belanda 10\%, susu skim 30\%, susu fullcream bubuk $29 \%$, whypedceram $12 \%$, gula $16 \%, 0,5 \%$ karagenan dan kuning telur. Bahan-bahan dihomogenisasi menggunakan mixer(1000 rpm) dan kemudian dipasteurisasi pada suhu $80^{\circ} \mathrm{C}$ selama 30 detik. Campuran didinginkan pada suhu $5^{\circ} \mathrm{C}$ selama 4 jam. Es krim dimix kembali selama 15 menit. Dua kultur murni Bakteri Asam Laktat Lactobacillus plantarum dan Streptococcus thermophillus tanpa di enkapsulasi dan terenkapsulasi masing-masing di inokulasi ke dalam campuran es krim sebanyak $4 \%$ kemudian di inkubasi pada suhu $37^{\circ} \mathrm{C}$ hingga selama 4 jam. Setelah 4 jam, es krim disimpan pada suhu $-28^{\circ} \mathrm{C}$.

\subsubsection{Parameter Pengamatan}

Penelitian berdasarkan pengaruh viabilitas BAL selama penyimpanan 56 hari dengan selang waktu pengamatan setiap 14 hari. Parameter yang diamati dalam penelitian terdiri dari: (1) Total Bakteri Asam Laktat menggunakan metode Total Plate Count (TPC), (2) Derajat Keasaman (pH), (3) Total Asam Tertitrasi, (4) Ketahanan pada simulasi asam lambung (pH 2), (5) Ketahanan pada Garam Empedu (0.5\%), (6) Overrun (tanpa penyimpanan), (7) uji organoleptik (uji hedonik).

\subsubsection{Desain Penelitian}

Desain penelitian menggunakan Rancangan Acak Lengkap (RAL) pola faktorial berdasarkan dua faktortial dengan dua kali ulangan. Faktor pertama adalah penggunaan jenis BAL (Lactobacillus plantarum bebas (LpB), Lactobacillus plantarum enkapsulasi (LpE), Streptococcus thermopillus bebas (StB), dan Streptococcus thermopillus enkapsulasi (StE)). Faktor kedua adalah lama penyimpanan es krim probiotik(0 (kontrol), 14, 28, 42, dan 56 hari). Sehingga diperoleh kombinasi perlakuan $4 \times 5 \times 2$ atau sebanyak 40 perlakuan. Penjabaran perlakuan dapat dilihat pada tabel 1 matriks perlakuan penelitian

\begin{tabular}{cccccc}
\hline BAL & P0 & P1 & P2 & P3 & $\begin{array}{c}\text { P } \\
4\end{array}$ \\
\hline \multirow{2}{*}{ LpB } & $\begin{array}{c}\text { LpB. } \\
\text { P0 }\end{array}$ & $\begin{array}{c}\text { LpB. } \\
\text { P1 }\end{array}$ & $\begin{array}{c}\text { LpB. } \\
\text { P2 }\end{array}$ & $\begin{array}{c}\text { LpB. } \\
\text { P3 }\end{array}$ & $\begin{array}{c}\text { Lp.P } \\
4\end{array}$ \\
\hline \multirow{2}{*}{ LpE } & $\begin{array}{c}\text { LpE. } \\
\text { P0 }\end{array}$ & $\begin{array}{c}\text { LPE. } \\
\text { P1 }\end{array}$ & $\begin{array}{c}\text { LpE. } \\
\text { P2 }\end{array}$ & $\begin{array}{c}\text { LpE. } \\
\text { P3 }\end{array}$ & $\begin{array}{c}\text { LpE } \\
. P 4\end{array}$ \\
\hline \multirow{2}{*}{ StB } & $\begin{array}{c}\text { StB. } \\
\text { P0 }\end{array}$ & $\begin{array}{c}\text { StB. } \\
\text { P1 }\end{array}$ & $\begin{array}{c}\text { StB. } \\
\text { P2 }\end{array}$ & $\begin{array}{c}\text { StB.P } \\
3\end{array}$ & $\begin{array}{c}\text { StB } \\
. P 4\end{array}$ \\
\hline \multirow{2}{*}{ StE } & StE. & StE. & StE. & StE.P & StE. \\
& P0 & P1 & P2 & 3 & P4 \\
\hline
\end{tabular}

\subsubsection{Analisa Data}

Data dianalisis dengan metode deskripsi kuantitatif antar perlakuan. Data secara statistik diolah menggunakan sidik ragam ANOVA, apabila terdapat pengaruh yang nyata maka dilanjutkan dengan uji Duncan untuk mengetahui perbedaan antar perlakuan

\section{HASIL DAN PEMBAHASAN}

\subsection{Total Bakteri Asam Laktat}

Pengujian total bakteri asam laktat (BAL) pada es krim bertujuan mengetahui banyaknya BAL yang dapat bertahan pada suhu beku selama penyimpanan. Hasil dari pengujian total bakteri asam laktat dapat dilihat pada Gambar 01. Hasil analisa ANOVA penyimpanan beku menunjukkan 
bahwa lama penyimpanan berpengaruhnyata $(\mathrm{P}<0,05)$ terhadap total BAL.Berdasarkan Gambar 01 total bakteri asam laktat selama penyimpanan. Lactobacillus plantarum dan Streptococcus thermopillus bebas mengalami penurunan dan viabilitas masing-masing sebesar 1.25 Log CFU g ${ }^{-1}$ (12\%) dan 2.56 Log CFU g ${ }^{-1}$ (25\%). Sedangkan Lactobacillus plantarum dan Streptococcus thermopillus terenkapsulasi mengalami penurunan dan viabilitas $0.20 \mathrm{Log}_{\mathrm{CFU} \mathrm{g}}{ }^{-1}(2 \%)$ dan 1,45 $\log _{\text {CFU g }}{ }^{-1}(14 \%)$.

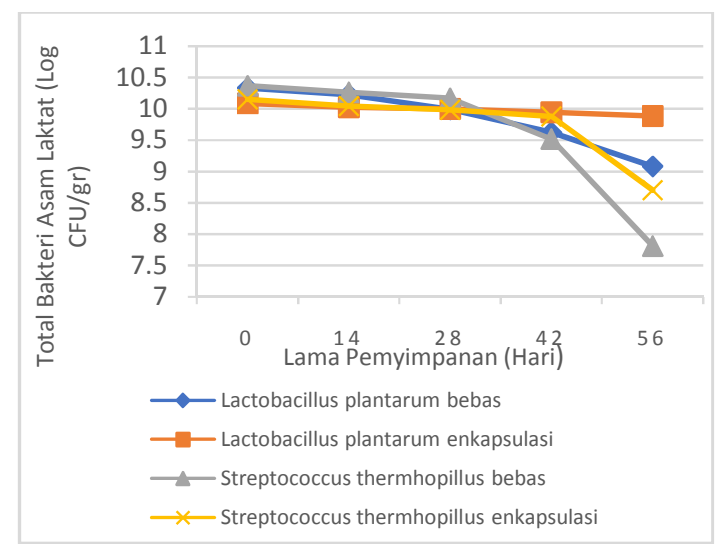

Gambar 1 Perubahan total bakteri asam laktat selama penyimpanan

Penggunaan enkapsulasi pada BAL menunjukkan jumlah BAL yang mampu bertahan selama penyimpanan beku lebih tinggi dibandingkan dengan BAL tanpa enkapsulasi. Alginat sebagai penyalut enkapsulasi memberi perlindungan BAL sehingga tidak terjadi kontak langsung antara BAL dan lingkungan es krim atau suhu beku dan sebagian besar sel BAL mampu bertahan selama penyimpanan. Hal tersebut sesuai dengan (Chávarri et al., 2010), bahwa enkapsulasi bertujuan melindungi bakteri dari factor-faktor lingkungan berbahaya bagi bakteri.

Sedangkan BAL tanpa enkpasulasi (bebas) mengalami kontak langsung dengan pembekuan menyebabkan permeabilitas membran sel bakteri menurun bahkan rusak akibat perubahan lingkungan. Perubahan permeabilitas sel menyebabkan larutan intraseluler terutama air dari sel keluar yang berakibat pada terjadinya kerusakan osmotik sel dan sel menjadi stress kemudian kehilangan keseimbangan. Hal ini sesuai dengan pernyataan (Cahyanti, 2008) bahwa Temperatur ekstrim menyebabkan inaktivasi enzim-enzim dan fungsi struktur sel. Kematian BAL akibat pembekuan dapat disebabkan oleh bakteri mengalami stressakibat kondisi lingkungan yang jauh berbeda dari suhu optimum pertumbuhannya sehingga mempengaruhi ketahanan hidupnya.

\section{ViabilitasLactobacillus}

plantarumterenkapsulasi selama penyimpanan lebih besar dari Streptococcus thermopillusterenkapsulasi. Hal ini disebabkan oleh perbedaan laju pertumbuhan sel masing-masing BAL dan lama penyimpanan beku. Laju Streptococcus thermopillus lebih cepat dari Lactobacillus plantarum.Lactobacillus plantarum membutuhkan waktu empat jam untuk melewati fase adaptasi pada lingkungannya sedangkan Streptococcus thermopillushanya membutuhkan waktu dua jam untuk melewati fase adaptasi dan memasuki fase eksponensial. Pada fase adaptasi terjadi pembelahan sel secara lambat dalam rangka penyesuaian diri terhadap lingkungan baru BAL. Setelah melewati fase adaptasi bakteri akan tumbuh membelah diri secara eksponensial dan menghasilkan banyak asam laktat sebagai hasil metabolit BAL. Hal ini menyebabkan perbedaan hasil asam laktat yang dihasilkan dari kedua bakteri pada saat pemeraman dalam es krim selama empat jam. Streptococcus thermopillus menghasilkan lebih banyak asam laktat menyebabkan matriks penyalut merenggang dan pori-pori penyalut membesar. Selain itu, selama penyimpanan kemungkinan terjadi pemutusan sebagian matriks sehingga mempengaruhi BAL.

Menurut (Ellenton, 1998) bahwa semakin lama penyimpanan maka jumlah sel yang diimobil juga semakin menurun. Penurunan jumlah sel yang terimobil disebabkan karena gel dari beads yang terbentuk dipengaruhi oleh adanya ion kalsium yang kekokohannya akan menurun 
apabila berada pada kondisi dimana terdapat agen pengkelat atau ion monovalen yang mengabsorb ion kalsium seperti asetat, laktat dan fosfat. (Florenzia, 2014) juga memaparkan bahwa selama penyimpanan suhu rendah terjadi pemutusan Ca-alginat, sehingga matriks sel imobil menjadi longgar.

\subsection{Nilai pH}

Pengukuran derajat keasaman es krim untuk mengetahui tingkat keasaman es krim selama masa penyimpanan es krim. Prinsip pengukuran nilai $\mathrm{pH}$ yaitu pengukuran konsntrasi ion $\mathrm{H}+$ oleh elektroda $\mathrm{pH}$ meter.

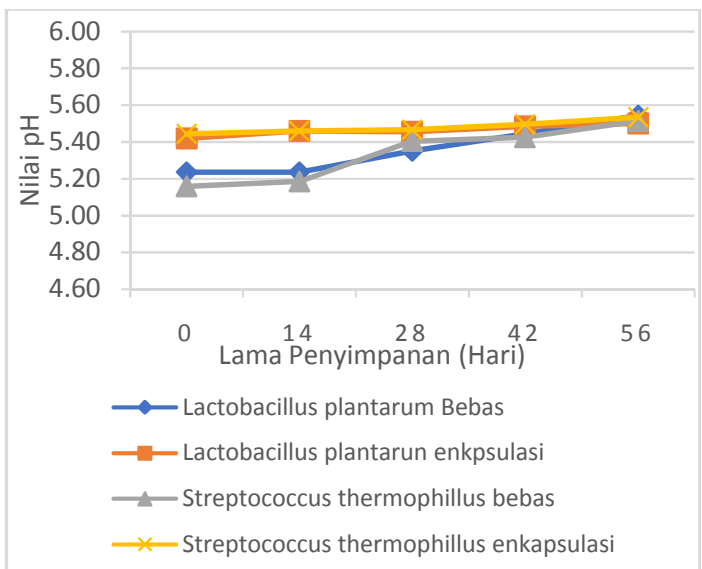

Gambar 2 Derajat keasaman $(\mathrm{pH})$ Es krim selama penyimpanan 56 hari

Hasil analisa ANOVA menunjukkan bawa lama penyimpanan berpengaruh nyata $(\mathrm{P}<0.05)$ terhadap derajat keasaman es krim. Berdasarkan Gambar 02 secara keseluruhan, terjadi kenaikan $\mathrm{pH}$ selama penyimpanan hari ke-0 hingga hari ke-56. Peningkatan nilai $\mathrm{pH}$ disebabkan perubahan aktifitas BAL.

Selama masa penyimpanan beku BAL mengalami dorman dan kematian akibat tekanan osmotik selama penyimpanan, menyebabkan BAL tidak mampu melakukan aktifitas metabolisme dan menghasilkan asam laktat selama penyimpanan beku. BAL terenkapsulasi memiliki $\mathrm{pH}$ yang relatif konstan disebabkan penyalut enkapsulasi yang membatasi hasil metabolit sel berupa asam laktat keluar dari penyalut enkapsulasi.
BAL tanpa perlakuan enkapsulasi mengalami kontak langsung dengan lingkungan beku. Suhu beku menyebabkan BAL mengalami perubahan membran sel yang menyebabkan terjadinya osmotic injury pada protein sel dan mengakibatkan kematian sel. Rendahnya sel BAL bertahan hidup menurunkan jumlah ion $\mathrm{H}+$ terdisosiasi pada es krim. Sehingga nilai $\mathrm{pH}$ mengalami kenaikan. Hal ini sesuai dengan pernyataan (Soro \& Thonart, 2010), bahwa penurunan konsentrasi ion $\mathrm{H}+$ dalam medium pertumbuhan mikroba pada suhu pembekuan disebabkan terganggunya keseimbangan sifat permeabilitas selektif pada membran sel terhadap elektrolit antara sel dengan lingkungannya. Hal ini mengakibatkan perubahan osmolaritas internal sel yang selanjutnya berdampak pada kematian sel. Peningkatan persentase elektrolit dalam sel yang erat hubungannya dengan penurunan persentase sel yang hidup.

\subsection{Total Asam Tertitrasi}

Analisa total asam dilakukan pada es krim adalah berdasarkan banyaknya asamasam yang bereaksi dengan $\mathrm{NaOH}$ dari keseluruhan jenis asam, baik asam yang terurai (terdisosiasi) maupun yang tidak terurai(tidak terdosiasi) dalam es krim

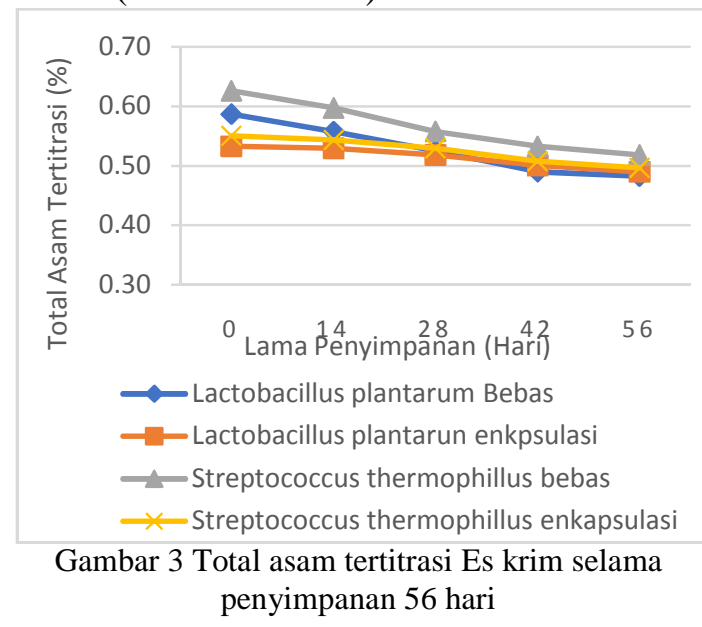

Hasil analisa ANOVA menunjukkan lama penyimpanan es krim probiotik berpengaruh nyata $(\mathrm{P}<0.05)$ terhadap total asam tertitrasi. Berdasarkan Gambar 03, bakteri asam laktar terenkapsulasi memiliki 
nilai total asam yang relative stabil. Hal tersebut disebabkan penyalut alginat yang melindungi BAL membatasi keluar masuknya nutrisi dan hasil metabolit sel sehingga asam laktat pada BAL terenkapsulasi tidak sepenuhnya tertitrasi. Sedangkan pada BAL bebas mengalami penurunan nilai total asam. Penurunan tersebut sejalan dengan kenaikan angka $\mathrm{pH}$ atau derajat asam pada es krim. Penurunan total asam juga disebabkan selama penyimpanan beku BAL mengalami dorman dan sebagian sel mengalami kematian. Kematian dipicu akibat tekanan osmotik lingkungan. Hal ini sesuai dengan pernyataan (Soro \& Thonart, 2010) bahwa pembekuan mengakibatkan perubahan osmolaritas internal sel yang selanjutnya berdampak pada kematian sel. Menurut (Mulyani S, Legowo, \& Mahani, 2008) kadar asam menurun seiring dengan menurunnya aktivitas bakteri, ditandai dengan semakinberkurangnya jumlah BAL yang masih hidup (beraktivitas).

\subsection{Ketahanan pada Simulasi Asam Lambung (pH2)}

Salah satu syarat diperolehnya manfaat probiotik dari Bakteri Asam Lambung ialah mampu bertahan selama melewati saluran pencernaan, diantaranya asam lambung dan garam empedu. Dalam penelitian ini kondisi asam lambung secara simulasi yaitu $\mathrm{pH}$ 2. Sebagaimana dengan pernyataan (Banyuaji, Rahayu, \& Utami, 2009), bahwa kondisi asam (pH2) merupakan kondisi yang hampir sama dengan kondisi asam lambung yang mana terdapat sekresi $\mathrm{HCl}$.

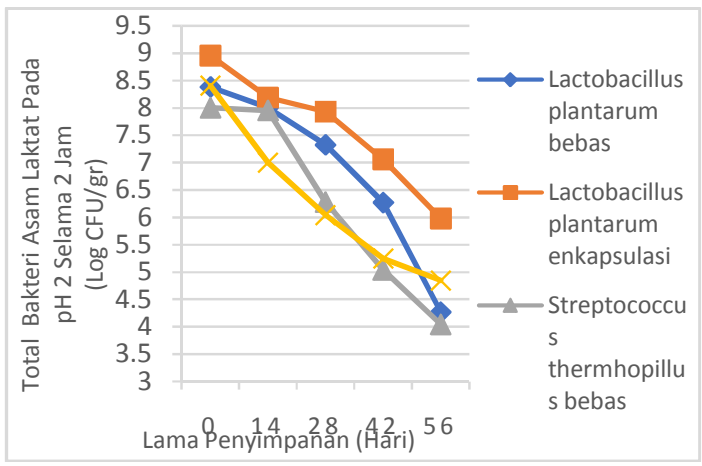

Gambar 4 Total Bakteri Asam Laktat es krim dalam simulasi asam lambung ( $\mathrm{pH} 2)$
Hasil analisa ANOVA menunjukkan bahwa lama penyimpanan berpengaruh nyata $(\mathrm{P}<0.05)$ terhadap viabilitas $\mathrm{BAL}$ pada simulasi asam lambung ( $\mathrm{pH} 2)$. Gambar 04. Memperlihatkan jumlah BAL mengalamai penurunan selama berada dalam $\mathrm{pH}$ rendah.

Sel BAL tanpa enkapsulasi (bebas) mengalami penurunan yang lebih besaryaitu Lactobacillus plantarum 4,11 Log CFU $\mathrm{gr}^{-1}$ dan Streptococcus thermopillus 3.96 Log CFU gr $^{-1}$ dengan presentase penurunan viabilitas masingmasing bakteri adalah31\% dan 38\%. Sedangkan BAL terenkapsulasi yaitu Lactobacillus plantarummengalami penurunan 2.98 Log CFU $\mathrm{gr}^{-1}$ dan Streptococcus thermopillus 3.56 Log CFU $\mathrm{gr}^{-1}$ dengan presentase penurunan viabilitas kedua bakteri sebesar $24 \%$ dan $37 \%$. Hal ini disebabkan Sel tanpa enkapsulasi akan mengalami kontak langsung pada kondisi $\mathrm{pH}$ rendah sehingga angka kematian sel lebih banyak dibandingkan dengan sel yang terenkapsulasi. Lamanya penyimpanan menyebabkan terjadi penurunan permeabilitas dan viabilitas sel sehingga selama berada dalam $\mathrm{pH}$ rendah BAL sulit melakukan aktifitas metabolisme dan tidak mampu bertahan. Asam seperti $\mathrm{HCl}$ yang ditemukan dalam lambung manusia merupakan oksidator kuat yang dapat mengoksidasi dan mengganggu keseimbangan biomolekuler sel.

Sel terenkapsulasi juga mengalami penurunan disebabkan membran dari matrik kalsium alginat terdegradasi pada kondisi asam rendah dan kehilangan kestabilannya akibat senyawa laktat yang dihasilkan bakteri selama penyimpanan. Kalsium alginat yang kehilangan kestabilan menyababkan ikatan kalsium alginat merenggang dan BAL mudah keluar dari penyalut serta cairan asam lebih mudah masuk dan menyebabkan kerusakan sel. Hal ini sesuai dengan pernyataan (Krasaekoopt et al., 2003), bahwa membran kalsium alginat mudah terdegradasi dengan cepat pada $\mathrm{pH}$ rendah dan kehilangan kestabilannya jika terdapat senyawa 
pengkelat seperti fosfat, laktat, dan sitrat. Hasil penelitian (Krasaekoopt, Bhandari, \& Deeth, 2004) dengan menggunakan TEM (transmission electronmicroscopy) perbesaran 6000X menunjukkan bentuk permukaan beads yang hanya diselubungi oleh satu matrik, yaitu natrium alginat menunjukkan masih banyaknya rongga yang tidak menutupi permukaan enkapsulasi sehingga bakteri dapat keluar atau menjadi jalan masuknya asam dan merusak sel bakteri.

\subsection{Ketahanan pada Garam Empedu $(0.5 \%)$}

Pengujian ketahanan pada garam empedu bertujuan untuk mengetahui pengaruh garam empedu pada konstenrasi $0.5 \%$ selama dua jam pada bakteri asam laktat (BAL) es krim selama penyimpanan. Pengujian ini dilakukan berdasarkan total bakteri asam laktat (BAL) setelah berada dalam garam empedu. Menurut (Adawiyah, Hafsan, \& Fatmawati, 2015) ketahanan terhadap garam empedu merupakan karakteristik yang penting bagi bakteri asam laktat, sebab berpengaruh terhadap aktivitasnya dalam saluran pencernaan, terutama saluran usus bagian atas tempat empedu disekresikan.

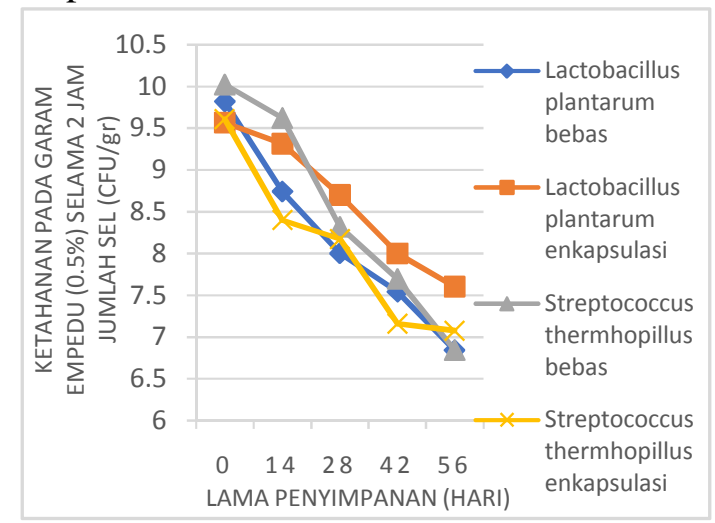

Gambar 5 Total Bakteri Asam Laktat (BAL) dalam simulasi garam empedu

Hasil analisa sidik ragam ANOVA lama penyimpanan berpengaruh nyata $(\mathrm{P}<0.05)$ terhadap viabilitas $\mathrm{BAL}$ pada $0.5 \%$ garam empedu. Berdasarkan gambar 05 secara keseluruhan, bakteri asam laktat baik bebas maupun terenkapsulasi mengalami penurun selama berada dalam garam empedu $0.5 \%$ selama 2 jam. Sel BAL tanpa enkapsulasi (bebas) mengalami penurunan yang lebih besar yaitu Lactobacillus plantarum 2,97 Log CFU gr $^{-1}$ dan Streptococcus thermopillus 3,17 Log $\mathrm{CFU} \mathrm{gr}^{-1}$ dengan presentase penurunan viabilitas masing-masing bakteri adalah $30 \%$ dan 32\%. Sedangkan BAL terenkapsulasi yaitu Lactobacillus plantarum mengalami penurunan 1,97 Log CFU $\mathrm{gr}^{-1}$ dan Streptococcus thermopillus 2,53 Log CFU gr $^{-1}$ dengan presentase penurunan viabilitas kedua bakteri sebesar $21 \%$ dan $26 \%$.

Penurun disebabkan selama penyimpanan sel bakteri telah mengalami penurunan permeabilitas sel terlebih dahulu sehingga sel ketika masuk pada kondisi garam empedu sel tidak mampu mentoleransi sifat racun dari garam empedu. Penurunan jumlah sel mengindikasikan bahwa sebagian sel mengalami lisis sebagai dampak dari garam empedu. Struktur amphipatik dari taurachlorate dan glycholate yang merupakan senyawa aktif mengemulsi lemak bereaksi dengan membrane sitoplasma bakteri sehingga struktur bakteri mengalami perubahan dan berujung pada terjadinya lisis bakteri. Keragaman struktur asam lemak pada membran sitoplasma bakteri menyebabkan perbedaan permeabilitas dan karakteristiknya sehingga mungkin mempengaruhi ketahannya terhadap garam empedu dan keberadaan garam empedu bagi mikroorganisme di dalam usus halus dapat juga disebut "Biological detergents" yaitu cairan yang memiliki kemampuan untuk melarutkan fosfolipid, kolesterol dan protein. Sebagian besar dari senyawa tersebut dapat menyusun membran sel, sehingga menyebabkan sel mikroorganisme menjadi hancur (lysis). Konsentrasi garam empedu yang tinggi akan menjadi racun dan zat antimikrobia yang sangat keras.

\subsection{Uji Organoleptik}

\subsubsection{Rasa}


Pengujian organoleptik rasa es krim dilakukan berdasarkan tingkat kesukaan panelis terhadap rasa es krim selama penyimpanan

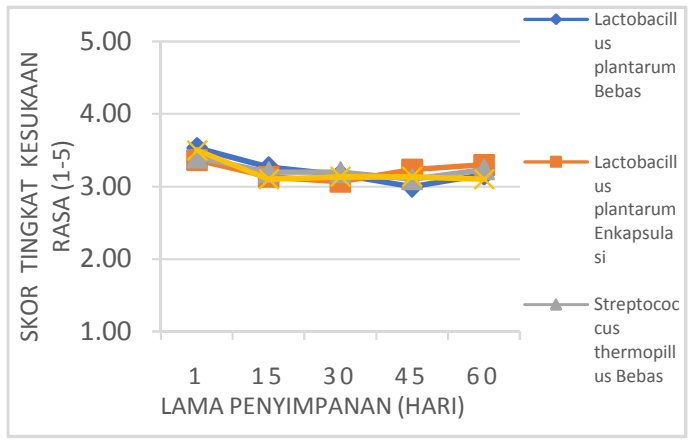

Gambar 6 Tingkat kesukaan rasa es krim selama penyimpanan

Hasil analisis sidik ragam ANOVA menunjukkan lama penyimpanan es krim probiotik menunjukkan tidak berpengaruh nyata $(\mathrm{P}>0.05)$ terhadap daya terima rasa es krim probiotik. Berdasarkan gambar 06 Skor rasa rata-rata diperoleh 3,22 menunjukkan adanya daya terima panelis terhadap es krim. Rasa manis dari es krim menutupi rasa asam dari es krim setelah pemeraman sehingga daya terima panelis cukup tinggi pada es krim. Selama penyimpanan bakteri tidak mampu menghasilkan asam laktat akibat suhu pembekuan, sehingga kadar asam pada es krim tidak mengalami kenaikan.

Tingkat penerimaan panelis secara keseluruhan pada produk fermentasi dengan starter BAL sangat dipengaruhi oleh tingkat keasaman produk, dimana tingkat keasaman yang semakin meningkat akan semakin menurunkan tingkat penerimaan panelis.

\subsubsection{Aroma}

Uji oranoleptik parameter aroma es krim probiotik dilakukan berdasarkan tingkat kesukaan panelis terhadap es krim probiotik selama penyimpanan. Hasil analisa hedonik pada aroma es krim probiotik dapat dilihat pada gambar 07 . Hasil analisa ANOVA lama penyimpanan tidak berpengaruh nyata $(\mathrm{P}>0.05)$ terhadap daya terima aroma es krim probiotik Berdasarkan gambar 07. Keseluruhan skor aroma es krim adalah 3.13. Skor menunjukkan aroma es krim cukup disukai oleh panelis.

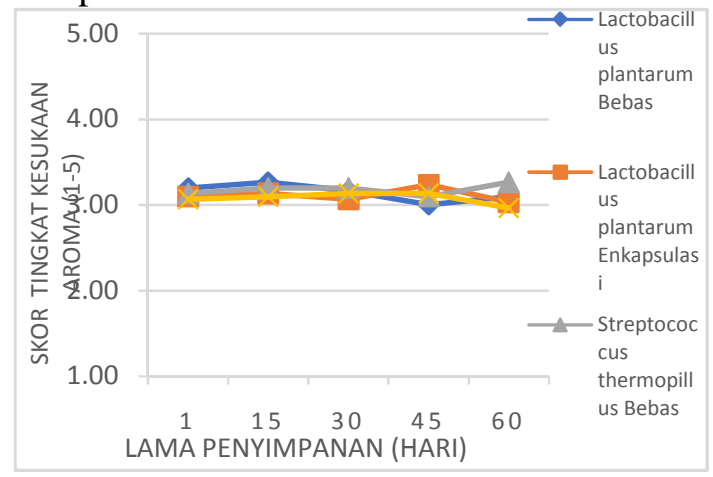

Gambar 7 Tingkat kesukaan aroma es krim selama penyimpanan

Aroma didominasi oleh aroma susu full cream dan aroma terung belanda. Aroma khas terung memberi nilai tambah pada aroma es krim. Selain itu, Komponen bahan penyusun es krim berperan terhadap pembentukan aroma es krim. Interaksi antara komponen protein, lemak, gula dan buah senyawa volatile buat terung belanda membentuk aroma yang disukai oleh panelis. komposisi lemak yang tepat pada bahan pangan akan mempengaruhi keseimbangan dari beberapa reaksi pembentukan flavour dan selanjutnya akan mempengaruhi flavour dan aroma secara keseluruhan dari makanan. Dan dilanjutkan oleh (Winarno, 2004), bahwa komponen pembentuk aroma pada buah-buahan adalah senyawa-senyawa ester yang bersifat mudah menguap atau senyawa volatile.

\subsubsection{Warna}

Pengujian organoleptik warna es krim dilakukan berdasarkan tingkat kesukaan panelis terhadap warna es krim selama penyimpanan . 


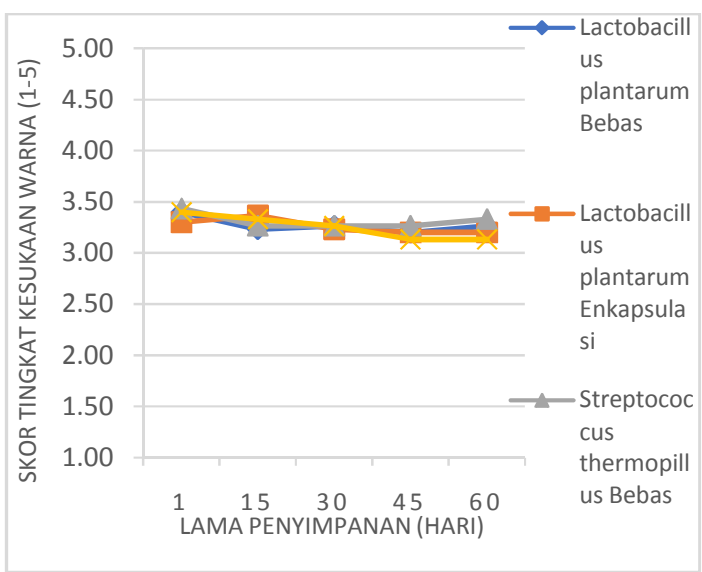

Gambar 8 Tingkat kesukaan aroma es krim selama penyimpanan

Hasil analisa ANOVA menunjukkan lama penyimpanan tidak berpengaruh nyata $(\mathrm{P}>0.05)$ antara tingkat kesukaan warna panelis terhadap penambahan BAL es krim selama penyimpanan. Berdasarkan gambar 08. es krim cukup diterima dan disukai oleh panelis dengan skor rata-rata 3,13. Warna es krim yang dihasilkan adalah warna merah mudah. Warna sebagian besar diperoleh dari warna susu dan terung belanda. Warna enkapsulasi yang sama dengan warna susu bubuk full cream mampu tertutupi dengan penambahan warna merah pekat dari daging buah terung belanda. Terung belanda memberi warna alami pada es krim sehingga dapat diterima oleh panelis.

\subsubsection{Tekstur}

Tekstur merupakan salah satu faktor sensori yang berkaitan dengan tingkat kekerasan dan kelembutan es krim. Pengujian organoleptik tekstur es krim dilakukan berdasarkan tingkat kesukaan panelis terhadap warna es krim selama penyimpanan.

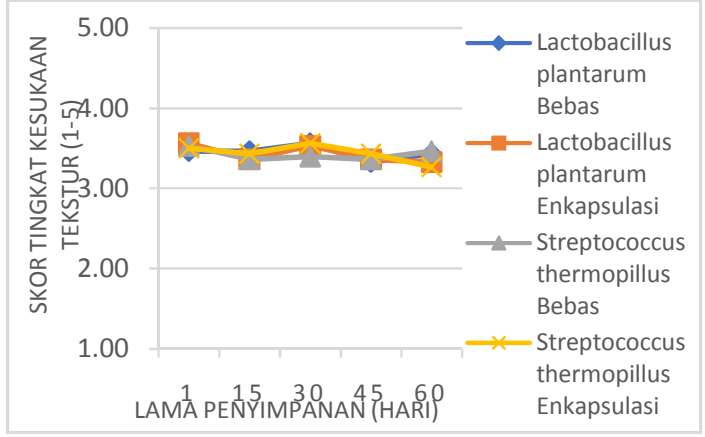

Gambar 9 Tingkat kesukaan tekstur es krim selama penyimpanan

Hasil analisa ANOVA menunjukkan lama penyimpanan tidak berpengaruh nyata $(\mathrm{P}>0.05)$ terhadap daya terima tekstur es krim probiotik. Berdasarkan gambar 09. Es krim memiliki nilai rata-rata 3.44 yaitu cukup disukai oleh panelis. Es krim memiliki daya kelembutan yang hampir sama walaupun dengan penambahan enkapsulasi BAL. Partikel enkapsulasi yang kecil tidak begitu mempengaruhi daya terima panelis. Kecilnya ukuran enkapsulasi membuat panelis tidak meyadari penanmbahan enkapsulasi pada es krim. Hal tersebut menunjukkan es krim masih memiliki tekstur yang baik walaupun dengan penambahan enkapsulasi. Hal ini sesuai dengan (Haryanti \& Zueni, 2015), bahwa tekstur yang baik pada es krim sehingga dapat disukai oleh panelis.

\subsection{Overrun}

Uji Overran bertujuan untuk mengetahui pengaruh enkapsulasi terhadap perubahan volume es krim selama. Nilai overrun merupakan salah satu syarat mutu dari es krim. Nilai overran menunjukkan nilai penambahan volume es krim setelah proses pengadukan. Berdasarkan gambar 10, nilai overrun es krim dengan penambahan BAL tanpa enkapsulasi memiliki nilai overrun yang lebih tinggi.

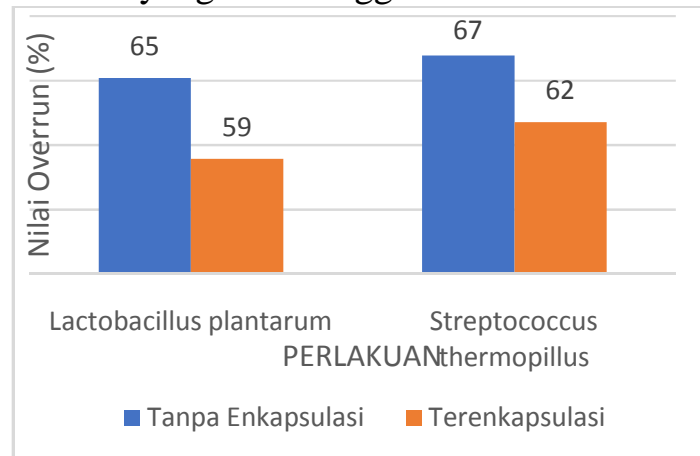

Gambar 10 Pengaruh enkapsulasi terhadap nilai overrun es krim

Hasil analisa sidik ragam ANOVA terhadap perlakuan bakteri menunjukkan berpengaruh nyata $(\mathrm{P}<0.05)$. Nilai overrun dipengaruhi oleh susunan bahan padatan es 
krim. Penambahan enkapsulasi membuat es krim tidak mengembang sempurna pada saat pengocokan akibat dari sedikitnya udara yang tertangkap. Hal ini sesuai dengan pernyataan (Farida, 2005), meningkatnya julah padatan adonan mengakibatkan nilai overran menurun.

Nilai overran es krim dengan penambahan enkapsulasi memenuhi standar nilai overrun es krim khususnya dalam skala rumah tangga. Hal ini sesuai dengan syarat mutu es krim oleh ([BSN]. Badan Standardisasi Nasional, 1995), yaitu 35$50 \%$ untuk skala rumah tangga, sedangkan70-80\% untuk skala industri.

\section{KESIMPULAN}

Kesimpulan yang diperoleh dari penelitian ini adalah sebagai berikut

1. Enkapsulasi berpengaruh nyata pada viabilias sel BAL yang ditambahkan ke dalam es krim. Enkapsulasi mampu melindungi BAL dari suhu beku selama delapan minggu. Hasil penelitian terhadap total BAL menunjukkan viabilitas sel terenkapsulasi lebih baik dibandingkan sel tanpa enkapsulasi selama penyimpanan beku.

2. Enkapsulasi pada BAL cukup mampu menghambat kerusakan dan kematian sel BAL selama berada dalam kondisi asam lambung dan garam empedu secara simulasi.

3. Es krim dengan penambahan BAL terenkapsul memiliki skor daya terima yang sama dengan BAL tanpa enkapsulasi dan cukup disukai oleh panelis baik yaitu segi rasa 3,22 , aroma 3,13, warna 3,28dan tekstur 3,44.

4. Penambahan BAL terenkapsulasi menurunkan nilai overrun pada es krim.

\section{DAFTAR PUSTAKA}

[BSN]. Badan Standardisasi Nasional. (1995). SNI 01-3713-1995. Es Krim. Jakarta: Badan Standardisasi Nasional. Adawiyah, Hafsan, \& Fatmawati. (2015). Ketahanan Bakteri Asam Laktat Asal
Dangke Terhadap Garam Empedu Sebagai Kandidat Probiotik. Prosidimg Seminar Nasional Mikrobiologi Kesehatan Dan Lingkungan Jurusan Biologi, Fakultas Sains Dan Teknologi, UIN Alauddin Makassar, 164-173.

Banyuaji, Rahayu, \& Utami. (2009). Viabilitas Lactobacillusacidopillus SNP dalam Es Krim. Jurnal Agritech, 28(4).

Cahyanti. (2008). Karakteristik Susu Kambing Fermentasi Menggunakan Starter Probiotik Lactobacillus acidophilus Pada Lama Penyimpanan yang Berbeda. Universitas Diponegoro. Semarang.

Chávarri, M., Marañón, I., Ares, R., Ibáñez, F. C., Marzo, F., \& Villarán, M. del C. (2010). Microencapsulation of a probiotic and prebiotic in alginatechitosan capsules improves survival in simulated gastro-intestinal conditions. International Journal of Food Microbiology. https://doi.org/10.1016/j.ijfoodmicro.2 010.06.022

Ellenton. (1998). Encapsulation Bifidobacteria. University of Guelph.

FAO/WHO. (2002). Guidelines for the evaluation of probiotics in food. Food and Agriculture Organization of the United Nations and World Health Organization Group Report.(London Ontario, Canada). FAO Food and Nutrition Paper 85.

Farida. (2005). kekerasan dan Overrum Es Krim yang Dibuat Menggunakan Susu Sapi Maupun Susu Kambing dengan Persentase Gula yang Berbeda. Universitas Jenderal Soedirman Fakultas Peternakan. Purwokerto.

Florenzia. (2014). Pengaruh Penambahan Isomalt danLama Penyimpanan terhadap Ketahanan Lactobacillus acidophilus Fncc 0051 Terimobildalam Gel Alginat pada Asam Lambung danGaram Empedu Secara In Vitro. Universitas Katolik Widya Mandala Surabaya. Surabaya. 
Gilliland, S. E., Staley, T. E., \& Bush, L. J. (1984). Importance of Bile Tolerance of Lactobacillus acidophilus Used as a Dietary Adjunct. Journal of Dairy Science. https://doi.org/10.3168/jds.S00220302(84)81670-7

Haryanti, N., \& Zueni, A. (2015). Identifikasi Mutu Fisik, Kimia Dan Organoleptik Dengan Variasi Susu Krim. Agritepa.

Krasaekoopt, W., Bhandari, B., \& Deeth, H. (2003). Evaluation of encapsulation techniques of probiotics for yoghurt. International Dairy Journal. https://doi.org/10.1016/S09586946(02)00155-3

Krasaekoopt, W., Bhandari, B., \& Deeth, H. (2004). The influence of coating materials on some properties of alginate beads and survivability of microencapsulated probiotic bacteria. International Dairy Journal. https://doi.org/10.1016/j.idairyj.2004.0 1.004

Mulyani S, A. M., Legowo, A. A., \& Mahani. (2008). Viabilitas Bakteri Asam Laktat, Keasaman Dan Waktu Pelelehan EsKrim Probiotik Menggunakan Starter Lactobacillus casei dan Bifidobacterium bifidum. Universitas Diponegoro. Semarang.

Schmidt, A. (2006). Cytostatic factor: an activity that puts the cell cycle on hold. Journal of Cell Science. https://doi.org/10.1242/jcs.02919

Soro, \& Thonart. (2010). An improved test to study the changes in membran permeability during rehydration of freeze-dried Weissella paramesenteroides. The Open Biotechnology Journal, 4, 8-13.

Winarno. (2004). Kimia Pangan dan Gizi. Jakarta: gramedia Pustaka Utama. 